\title{
ISOTOPE STUDIES OF ICE CORES FROM A TEMPERATE ALPINE GLACIER (VERNAGTFERNER, AUSTRIA) WITH RESPECT TO THE MELTWATER FLOW
}

by

\author{
H. Oerter, D. Baker, W. Stichler and W. Rauert
}

(GSF-Institut für Radiohydrometrie, D-8042 Neuherberg, Oberschleissheim, West Germany)

\section{ABSTRACT}

Core drillings were carried out in 1979 and 1983 on the temperate Alpine glacier Vernagtferner, Ötztal Alps, Austria. In addition, studies on the variation of the water table of the firn were carried out in the bore holes. The ${ }^{18} \mathrm{O},{ }^{2} \mathrm{H}$ and ${ }^{3} \mathrm{H}$ content of the cores, as well as the electrical conductivity, were measured. The isotope profiles and the electrical conductivity of the 1983 core display a strong damping in comparison with the profiles from the 1979 core for the depth from 17 to 20 $\mathrm{m}$ (10.5 to $13 \mathrm{~m}$ water equivalent) below the surface. In the 1983 core, the ${ }^{3} \mathrm{H}$ contents are lower, and the ${ }^{2} \mathrm{H}$ and ${ }^{18} \mathrm{O}$ contents are more homogenized. This core section lies between the lower and upper limits of the water table fluctuations from 1979 to 1982, and it is also assumed that the transition from firn to ice takes place at this depth of the glacier. The most reasonable explanation for this damping is that within the range of the firn water table important isotopic and chemical exchanges between the meltwater and the porous medium (firn) take place. It is also possible that a small amount of meltwater is included in the firn while it is changing into ice.

\section{INTRODUCTION}

On the temperate Alpine glacier Vernagtferner, Ötztal Alps, Austria, core drillings were carried out in 1979 (bore holes I-III) (Oerter and others 1982) and again in 1983 (IV-VI). The sites of bore holes I-V (Fig.1) were located in the accumulation area, and bore hole VI was located near the mean equilibrium line (not shown in Figure 1). The investigations of the isotope content, fission products and structural parameters of the core material of bore holes I, II and III from 1979 are complete and the results published (Drost and Hof reiter 1982, Good 1982, von Gunten and others 1982, Oerter and Rauert 1982, Stichler and others 1982). The present paper deals with the isotope $\left({ }^{3} \mathrm{H},{ }^{18} \mathrm{O},{ }^{2} \mathrm{H}\right)$ and electrical conductivity measurements of core IV, with the aim of investigating the variations in isotope contents during the period from 1979 to 1983.

Bore hole IV was drilled on 5 and 6 March 1983, yielding a core of length $39.9 \mathrm{~m}$, which corresponds to $30.1 \mathrm{~m}$ water equivalent (w.e.). The drilling site was only $10 \mathrm{~m}$ from the site of bore hole I in 1983 (Fig.1). Bore hole I has advanced $39.8 \mathrm{~m}$ since March 1979, corresponding to a mean surface flow velocity of the glacier in that time of $9.9 \mathrm{~m} \mathrm{a}^{-1}$. The vertical component of the movement was $7.7 \mathrm{~m}$, corresponding to a mean value of $1.9 \mathrm{~m} \mathrm{a}^{-1}$. For the isotope measurements the core was cut parallel to its axis into two equal parts. One half, with a cross-section of about $22 \mathrm{~cm}^{2}$, was further cut perpendicular to the axis into pieces $5 \mathrm{~cm}$ long. These pieces were melted, and the electrical conductivity measured, and afterwards ${ }^{3} \mathrm{H},{ }^{2} \mathrm{H}$ and ${ }^{18} \mathrm{O}$ contents were determined.

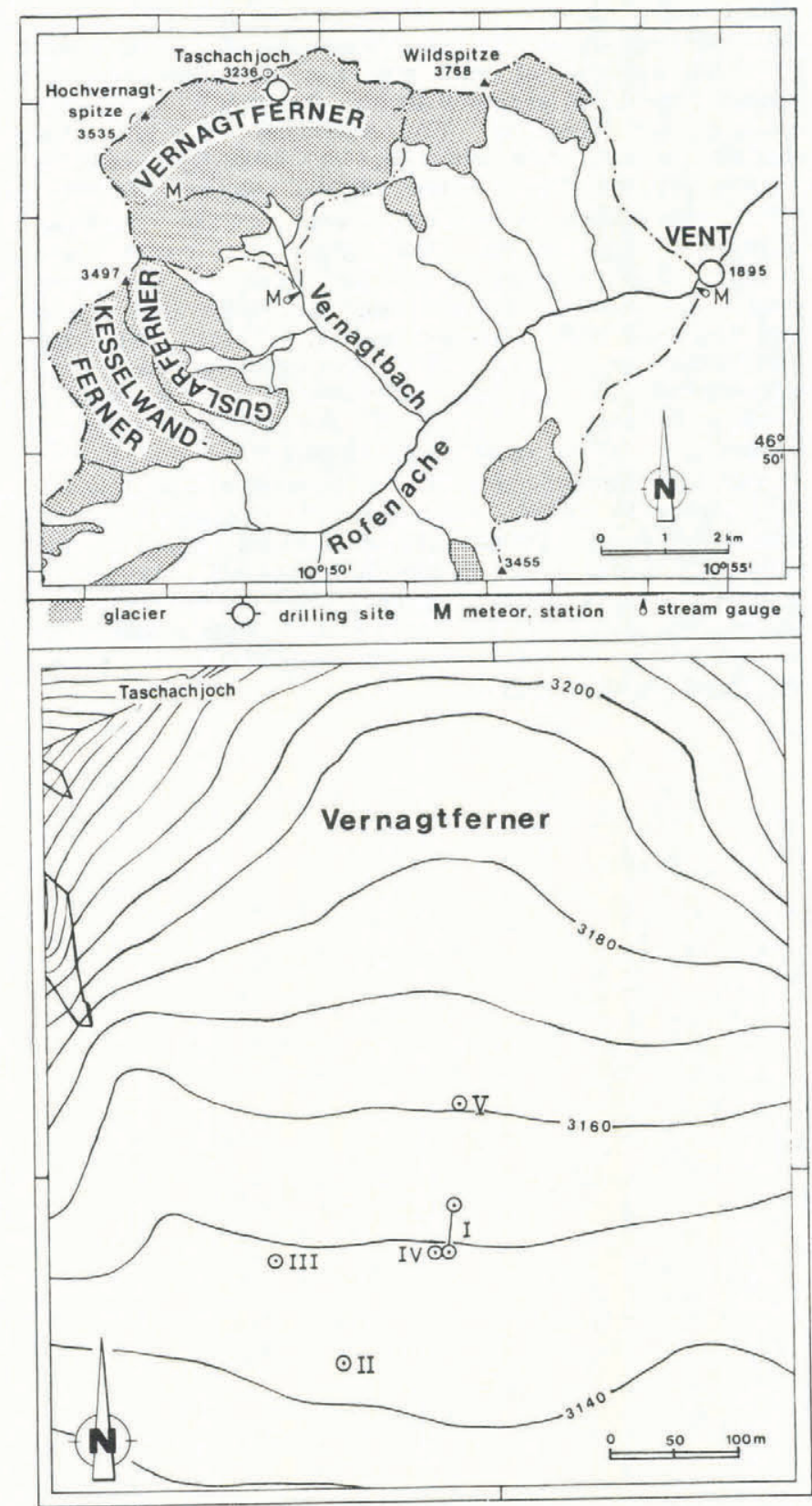

Fig.1. Map of the investigation area of Vernagtferner in the Ötztal Alps (Austria), and of the location of the drilling sites in 1979 (bore holes I, II, III) and 1983 (IV, V). The two positions of bore hole I show its movement from March 1979 to March 1983. 
a

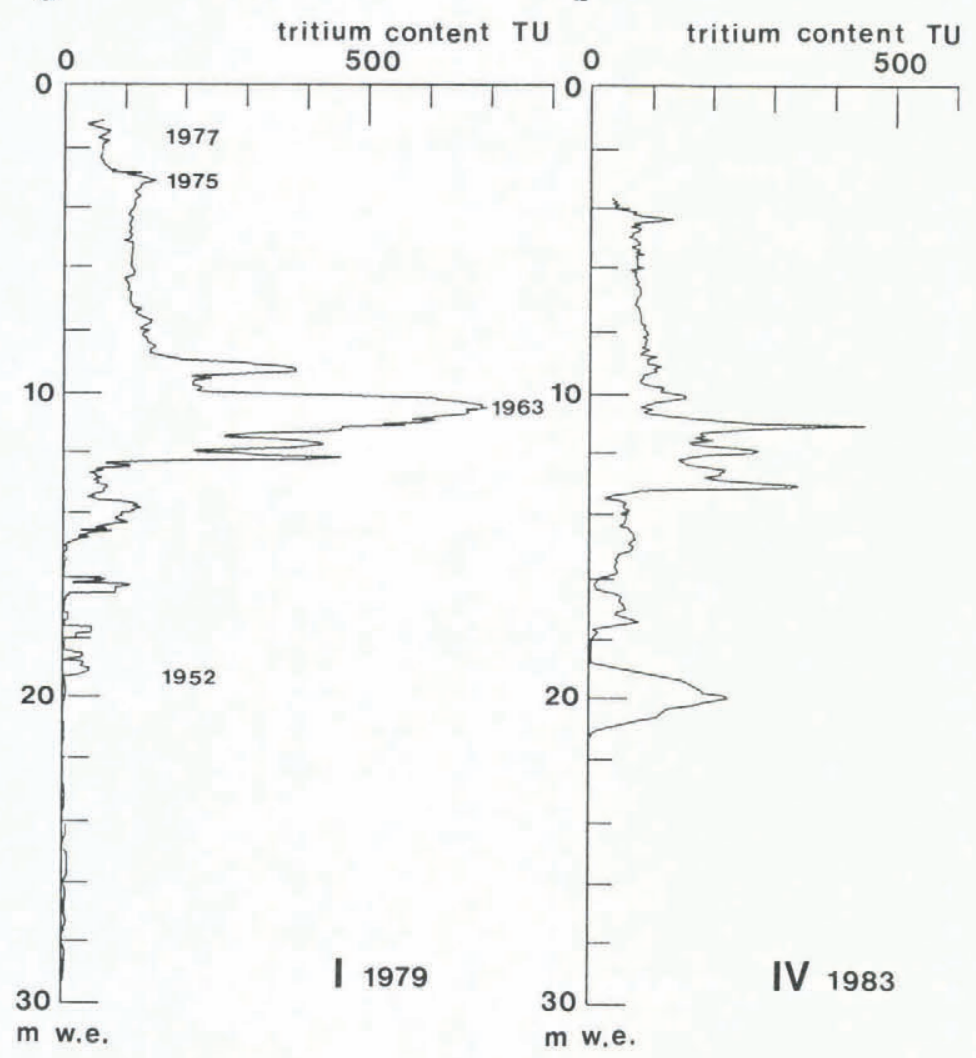

C

d

el. conductivity $\mu \mathrm{S} / \mathrm{cm} \quad$ el. conductivity $\mu \mathrm{S} / \mathrm{cm}$

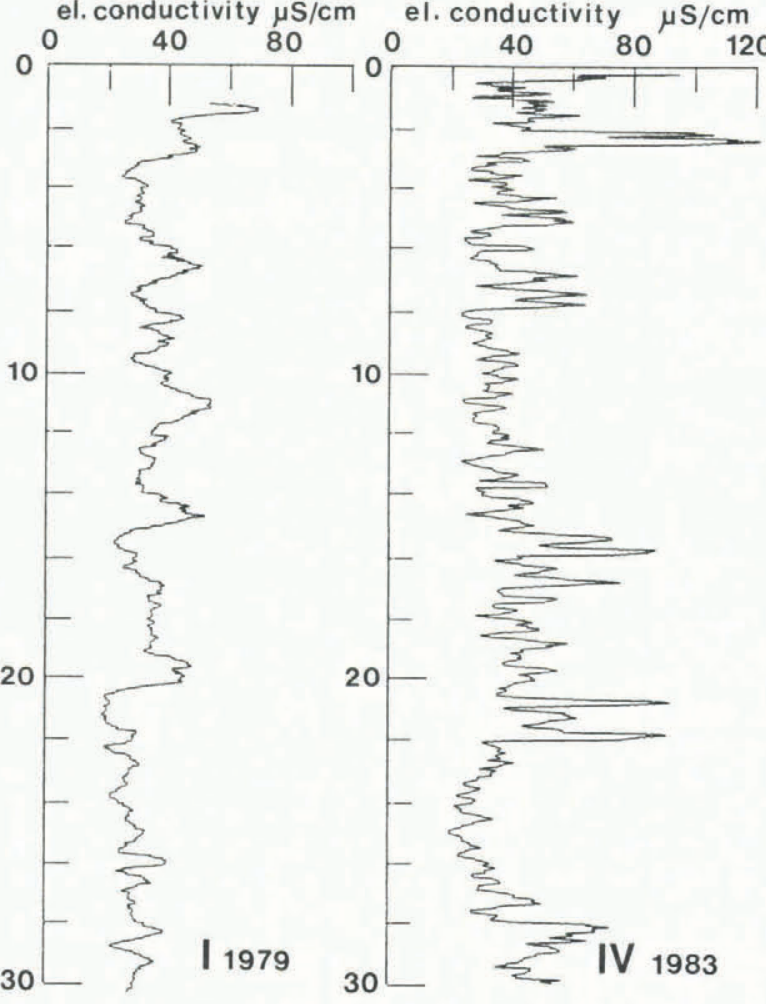

m w.e.

Fig.2. (a) ${ }^{3} \mathrm{H}$ content of core I (1979) (Oerter and Rauert 1982), (b) ${ }^{3} \mathrm{H}$ content of core IV (1983), (c) electrical conductivity (normalized to $20^{\circ} \mathrm{C}$ ) of core I (1979) (running mean values of 10 samples, $2.5 \mathrm{~cm}$ long each, plotted), (d) electrical conductivity (normalized to $25^{\circ} \mathrm{C}$ ) of core IV (running mean values of 5 samples, $5 \mathrm{~cm}$ long each, plotted).

\section{CONDUCTIVITY CONTENT \\ AND \\ ELECTRICAL}

\subsection{Tritium content}

The ${ }^{3} \mathrm{H}$ contents of most of the samples were measured by direct liquid scintillation counting of $10 \mathrm{ml}$ water samples for a time of 500 to $1000 \mathrm{~min}$ each, which yields a detection limit of about $10 \mathrm{TU}^{*}$. Details of the measuring technique may be found in Eichinger and others (1981).

Figures 2(a) and (b) show the ${ }^{3} \mathrm{H}$ content of core I (Oerter and Rauert 1982) in comparison with the ${ }^{3} \mathrm{H}$ content of core IV plotted against the depth in meters of water equivalent.

Core IV displays high ${ }^{3} \mathrm{H}$ values in the depth between 10 and $13 \mathrm{~m}$ w.e., as was expected from the ${ }^{3} \mathrm{H}$ content of core I. This increase in ${ }^{3} \mathrm{H}$ content in the deposited precipitation is due to the nuclear weapon tests performed mainly between 1953 and 1962. The high ${ }^{3} \mathrm{H}$ values appear in core IV at about $0.9 \mathrm{~m}$ w.e. deeper than in core I. The lengths of the sections with high ${ }^{3} \mathrm{H}$ contents in cores I and IV are in good agreement, but the amounts of ${ }^{3} \mathrm{H}$ differ. The ${ }^{3} \mathrm{H}$ content should have decreased by a factor of 0.8 due to radioactive decay during the period 1979-1983 (see also Fig.4), but in fact decreased by a factor of about 0.5 . This means that in addition to the radioactive decay another decrease took place. This additional decrease is possibly due to the effects of the water table in the firn, and to the seepage of meltwater there. This point will be discussed in more detail in section 4.

An unexpectedly high ${ }^{3} \mathrm{H}$ content was measured in core IV between the depth of 19 to $21 \mathrm{~m}$ w.e.

* $1 \mathrm{TU}$ (tritium unit) $\hat{=} 3.2 \mathrm{pCi}$ or $0.12 \mathrm{~Bq}$ per litre of water. All ${ }^{3} \mathrm{H}$ contents presented are referred to the date of sampling unless another reference date is given.
According to the dating of core I (Oerter and Rauert 1982, Stichler and others 1982) these firn and ice layers come from precipitation during the years 1951 to 1954 As the ${ }^{3} \mathrm{H}$ values are about 200 TU (the original ${ }^{3} \mathrm{H}$ content of the precipitation would have been at least $1000 \mathrm{TU})$, which is larger than expected for this period, we have to assume a contamination of the firn layers by meltwater. This meltwater must either originate from precipitation of the bomb-test period or have been in contact with firn layers from that time under equilibrium conditions. During the drilling these ice cores were wet and water was in the bore hole. At this stage in our investigations we have no definite explanation for the high ${ }^{3} \mathrm{H}$ content at this depth.

We calculate a value of either $1.3 \mathrm{~m}$ w.e. or $0.9 \mathrm{~m}$ w.e. for the mean accumulation rate from March 1979 to March 1983, depending on whether the small peak at 1975 or the more pronounced peaks around 1963 are used as reference layers.

\subsection{Electrical conductivity}

Figure 2(c) shows the measured electrical conductivity of the 1979 core I, and Figure 2(d) shows the same for the 1983 core IV. Different instruments were used for the electrical conductivity measurements in 1979 and 1983. Both were working with a temperature compensation, referring the results to a reference temperature of $20^{\circ} \mathrm{C}$ in 1979 and of $25^{\circ} \mathrm{C}$ in 1983 (correction factor $0.021 \mathrm{~K}^{-1}$ ). Another difference between the measuring techniques was that in 1983 the electrical conductivity was measured immediately after the samples had been melted, whereas in 1979 there was a time lag of some months. In Figure 2(c) and (d) the running mean values are plotted, for core I over 10 samples (each sample is $2.5 \mathrm{~cm}$ long) and for core IV over 5 samples (each sample is $5 \mathrm{~cm}$ long). The measured minimum values are about $20 \mu \mathrm{S} \mathrm{cm}$, and the maximum values up to about $200 \mu \mathrm{S} \mathrm{cm}^{-1}$. The 
curve of electrical conductivity for core IV reveals relatively regular variations such that one might assume they represent annual variations. Some, but not all, peaks coincide with summer dust layers which had already been recognized during the core processing in the field.

The electrical conductivity of cores I and IV both show a similar general pattern. The minimum values compare well, but the maximum values are higher in 1983. The larger peaks appear in both cores, with a downward shift of core IV relative to core I. There is only one exception: the peak at $11 \mathrm{~m}$ w.e. in core I (also the depth of the peak due to bomb tritium) cannot be found in core IV. This illustrates that not only the ${ }^{3} \mathrm{H}$ content but also the electrical conductivity at that depth is smaller in 1983 than in 1979.

\section{THE WATER TABLE IN THE FIRN}

Previous investigations of meltwater flow on and within the Vernagtferner demonstrated the build-up of a seasonal water table within the glacier at a depth of about 17 to $20 \mathrm{~m}$ below the glacier surface (Oerter and Moser 1982). The seasonal fluctuations of the water table are correlated with meltwater production on the glacier surface and with meltwater seepage through the firn (Fig.3). The thickness of the water-bearing firn layer increases at the beginning of the ablation season, up to $4 \mathrm{~m}$ thickness in some years, and decreases again at the end of the ablation season. The water table is also influenced by crevasses in the firn area which cause drainage of the water-bearing firn layer. Thus the water table drops in the proximity of a crevasse. This means that in the area around an ice core a large water-bearing layer could have existed during certain years, whereas in other years, when this area reached a crevasse, only a thin water-bearing layer might have existed, due to the draining effect of the crevasse.

Tracer experiments on the Vernagtferner showed that intraglacial meltwater flow takes place, and that this meltwater finds its way to the glacier terminus within a few days (Behrens and others 1982). The calculated flow velocity within the firn water body was about $6 \mathrm{~m} \mathrm{~d}^{-1}$. It is most likely that an isotopic and chemical exchange takes place between the passing meltwater and the porous firn, because the firn is assumed to be water saturated and the liquid and solid phases are in equilibrium. Such an exchange causes a damping of the original isotope content in the firn water body.

Figure 3 also shows the flow line of two firn layers containing two pairs of ${ }^{3} \mathrm{H}$ peaks correlated between cores I and IV (see Fig.4).

\section{CHANGES IN THE ISOTOPE CONTENT}

Figure 4 shows the isotope content of core IV from 8 to $18 \mathrm{~m}$ depth w.e. The results for core I are also plotted, with the depth scale shifted $0.9 \mathrm{~m}$ w.e. downwards (this shift yields the best fit between the ${ }^{3} \mathrm{H}$ content of both cores). The ${ }^{3} \mathrm{H}$ content of core I (Fig.4(a)) was multiplied by a factor of 0.8 to compensate for the radioactive decay which took place between 1979 and 1983. The biggest changes in ${ }^{3} \mathrm{H}$ are observed between 10 and $13 \mathrm{~m}$ w.e., as already mentioned above. From Figure 3 we note that the two peaks at 9.2 and $12.2 \mathrm{~m}$ w.e. in core I (Fig.2(a)), corresponding to the peaks at 10.1 and $13.1 \mathrm{~m}$ w.e. in core IV, were submerged beneath the firn water table several times in the intervening four years. Apparently, a higher dilution of the ${ }^{3} \mathrm{H}$ content takes place in the more porous firn layers in the water table, and they thus display a greater decrease in the ${ }^{3} \mathrm{H}$ content than do the more compact layers, which mostly coincide with dust layers (at 10.9, 12.0, and $13.05 \mathrm{~m}$ depth w.e. in core I).

Furthermore, the measurements of ${ }^{2} \mathrm{H}$ and ${ }^{18} \mathrm{O}$ contents over this depth range demonstrate a similar effect. In both cases the very marked minimum of core I (Stichler and others 1982) cannot be found in core IV (Fig.4(b)), where only a small peak appears at the

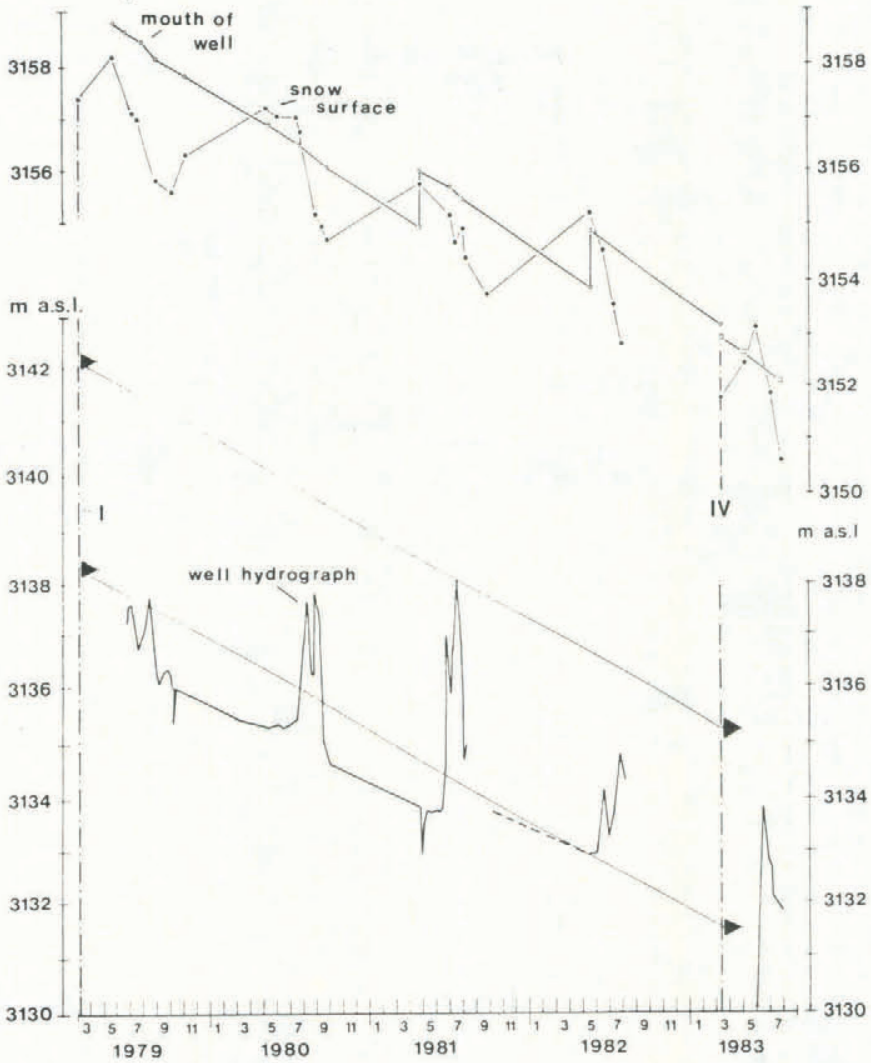

Fig.3. Record of water level (well hydrograph) in bore hole I from 1979 to 1982 and in bore hole IV for 1983. The elevation change of the well opening and of the snow surface is also plotted. Note that a pipe was put into bore hole I in May 1979 to reinforce the upper $4 \mathrm{~m}$, and a water-level recorder was mounted on the well opening. The vertical uplift of the well opening in 1981 and 1982 is due to extra pieces of pipe being added. In 1983 a pipe was put into bore hole IV immediately after drilling. The triangles mark the flow lines of two pairs of ${ }^{3} \mathrm{H}$ peaks (at 9.2 and $12.2 \mathrm{~m}$ w.e. in core $\mathrm{I}$, and 10.1 and $13.1 \mathrm{~m}$ w.e. in core IV).

corresponding depth. The remaining minimum at a depth of $10.9 \mathrm{~m}$ w.e. lies in a horizon with a marked dust layer, and is obviously not related to the original minimum peak of core I. Not only have the minimum values been damped since 1979, but also the maximum values in the firn layers below (these layers do not display the absolute maximum of the ${ }^{18} \mathrm{O}$ content of core I (Stichler and others 1982: fig.4)). This illustrates that the isotope content becomes more homogeneous in the firn water body. The mean ${ }^{18} \mathrm{O}$ content of the core section shown (Fig.4(b)) decreased slightly from $-14.3^{\circ} \%$ (core I) to $-14.6^{0} / 00$ (core IV).

The analysis of core I by Stichler and others (1982) demonstrated that the variations of the deuterium excess $d\left(d=\delta^{2} \mathrm{H}-8 \delta^{18} \mathrm{O}\right)$ can be used to determine yearly firn layers. In fact, along the section of core IV under discussion the variations of the excess are also present, with only a slightly smaller amplitude. This confirms the usefulness of the deuterium excess for the core analysis. The mean value of deuterium excess also increased from $6.7^{\circ} / 00$ in 1979 to $9.4^{0} / 00$ in 1983. An explanation for this effect cannot be given.

The downwards depth shift of $0.9 \mathrm{~m}$ w.e. which best fitted the results of the ${ }^{3} \mathrm{H}$ measurement, does not yield best results at all depths for the ${ }^{18} \mathrm{O}$ measurements or for the deuterium excess d. In general a shift of 1.1 $\mathrm{m}$ w.e. would be better for the comparison of ${ }^{18} \mathrm{O}$ and excess d.

Besides an exchange between meltwater and firn, another effect could also appear to be yielding more homogeneous $\delta^{18} \mathrm{O}$ values as well as ${ }^{3} \mathrm{H}$ and electrical 


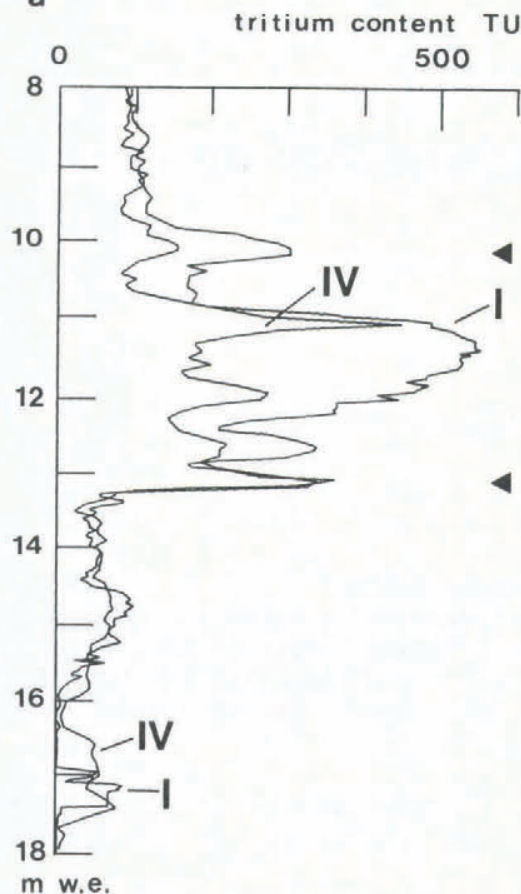

b

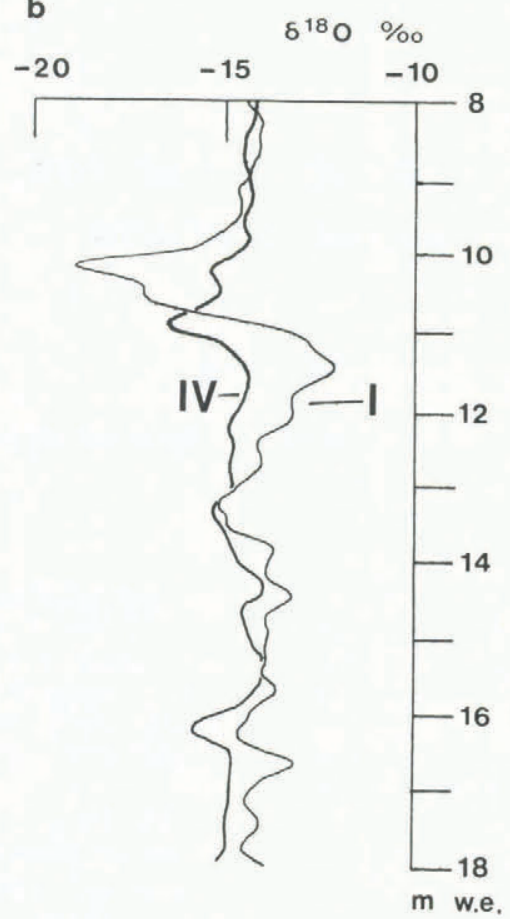

c

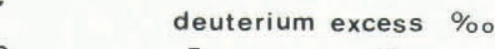

10

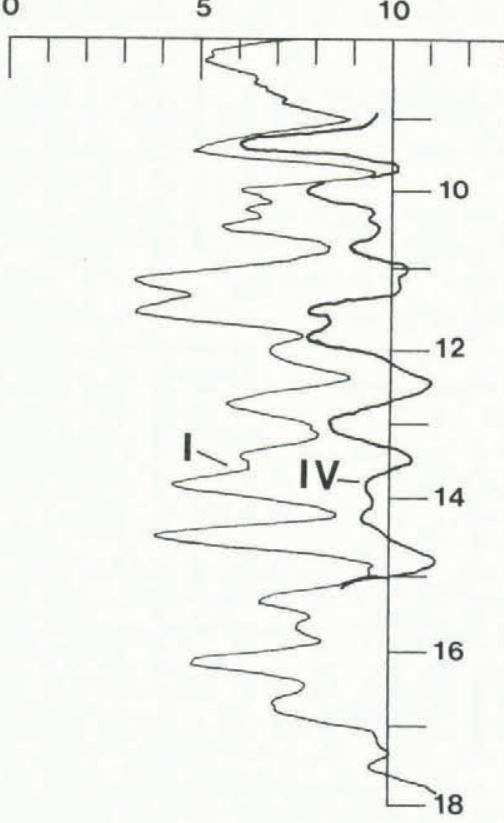

Fig.4. (a) ${ }^{3} \mathrm{H}$ content of core IV and of core I (Oerter and Rauert 1982). The ${ }^{3} \mathrm{H}$ contents of core I are referred to March 1983, and the depth scale for core I is shifted $0.9 \mathrm{~m}$ w.e. downwards to yield the best fit. The triangles mark the ${ }^{3} \mathrm{H}$ peaks of which the flow lines are shown in Fig.2. (b) Oxygen-18 content of core IV (running mean values over 5 samples, $5 \mathrm{~cm}$ long each) and of core I (Stichler and others 1982) (running mean values over 10 samples, $2.5 \mathrm{~cm}$ long each). The depth of core $\mathrm{I}$ is shifted $0.9 \mathrm{~m}$ downwards, as for the ${ }^{3} \mathrm{H}$ content. The ${ }^{18} \mathrm{O}$ content is indicated in terms of relative deviation $\delta^{18} \mathrm{O}$ from the international standard V-SMOW. The measuring accuracy is $\pm 0.15^{\circ} \%$. (c) Deuterium excess of core IV (running mean values over 5 samples, $5 \mathrm{~cm}$ long each) and that of core I (Stichler and others 1982) (running mean values over 10 samples, $2.5 \mathrm{~cm}$ long each). The depth of core $\mathrm{I}$ is shifted $0.9 \mathrm{~m}$ downwards, as for the ${ }^{3} \mathrm{H}$ content. The deuterium excess $d$ was calculated by $d=\delta^{2} \mathrm{H}-8 \delta^{18} \mathrm{O}$

conductivity values. If some amount of the meltwater remains in the liquid phase in the pores of the drained firn water body (density $0.75-0.85 \mathrm{~g} \mathrm{~cm}^{-3}$ ) during winter time, it will freeze and become part of the core when the core is removed from the bore hole in sub-freezing temperatures. In addition, small amounts of water remaining in firn pores can become trapped as the firn changes to ice.

In conclusion one can say that one possible reason for the changing isotope content within a temperate glacier is the firn water body, which appears on the Vernagtferner at a depth of about 10 to $12 \mathrm{~m}$ w.e. When using the ${ }^{18} \mathrm{O}$ or ${ }^{2} \mathrm{H}$ contents for analysis of an ice core from a temperate glacier emphasis should be laid on the deuterium excess.

\section{ACKNOWLEDGEMENTS}

We thank H Rufli (Berne) and E Heucke, H Rentsch, W Stadler (Munich), as well as all the others who helped us in preparing and carrying out the drilling operation and the laboratory work. We owe thanks to the Physics Institute of the University of Berne, Switzerland (Professor H Oeschger), for providing the drilling equipment, and to the Deutsche Forschungsgemeinschaft (German Research Association) for the financial support of the project, carried out in the framework of the "Sonderforschungbereich 81, Teilprojekt Al" (under the leadership of Professor $\mathrm{H}$ Moser) of the Technical University of Munich.

\section{REFERENCES}

Behrens H, Oerter H, Reinwarth O 1982 Results of tracer experiments with fluorescent dyes on Vernagtferner (Oetztal Alps, Austria) from 1974 to 1982. Zeitschrift für Gletscherkunde und Glazialgeologie 18(1): 65-83
Drost W, Hof reiter G 1982 Natural gamma logging of borehole I on Vernagtferner (Oetztal Alps, Austria). Zeitschrift für Gletscherkunde und Glazialgeologie 18(1): 47-52

Eichinger L, Forster M, Rast H, Rauert W, Wolf M 1981 Experience gathered in low-level measurement of tritium in water. In Low-level tritium measurement; proceedings of a consultants group meeting on low-level tritium measurement organized by the International Atomic Energy Agency and held in Vienna ... 1979. Vienna, International Atomic Energy Agency: 43-64 (IAEA-TECDOC 246)

Good W 1982 Structural investigations of snow and ice on core III from the drilling on Vernagtferner, Austria, in 1979. Zeitschrift für Gletscherkunde und Glazialgeologie 18(1): 53-64

Oerter H, Moser H 1982 Water storage and drainage within the firn of a temperate glacier (Vernagtferner, Oetztal Alps, Austria). International Association of Hydrological Sciences Publication 138 (General Assembly of Exeter 1982 - Hydrological Aspects of Alpine and High-Mountain Areas): $71-81$

Oerter H, Rauert W 1982 Core drilling on Vernagtferner (Oetztal Alps, Austria) in 1979: tritium contents. Zeitschrift für Gletscherkunde und Glazialgeologie 18(1): 13-22

Oerter H, Reinwarth O, Rufli H 1982 Core drilling through a temperate Alpine glacier (Vernagtferner, Oetztal Alps) in 1979. Zeitschrift für Gletscherkunde und Glazialgeologie 18(1): 1-11

Stichler W, Baker D, Oerter H, Trimborn P 1982 Core drilling on Vernagtferner (Oetztal Alps, Austria) in 1979: deuterium and oxygen-18 contents. Zeitschrift für Gletscherkunde und Glazialgeologie 18(1): 23-35

von Gunten H R, Rössler E, Gäggeler H 1982 Dating of ice cores from the Vernagtferner (Austria) with fission products and lead-210. Zeitschrift für Gletscherkunde und Glazialgeologie 18(1): $37-45$ 